\title{
PELANGGARAN HAK CIPTA OLEH LEMBAGA PEMERINTAH (STUDI KASUS PENAYANGAN FILM "SEJAUH KUMELANGKAH" PADA PROGRAM BELAJAR DARI RUMAH OLEH KEMENTERIAN PENDIDIKAN DAN KEBUDAYAAN) Copyright Infringement by Government Agencies (Case Study of "How Far I'll Go" Film Broadcasting 'Learn From Home' Program by the Ministry of Education and Culture)
}

\author{
Dewi Analis Indriyani \\ Badan Penelitian dan Pengembangan Hukum dan HAM, Jakarta \\ dewianalis.peneliti@gmail.com
}

Tulisan Diterima: 15-12-2020; Direvisi: 12-02-2021; Disetujui Diterbitkan: 24-02-2021

DOI: http://dx.doi.org/10.30641/kebijakan.2021.V15.95-110

\begin{abstract}
Abstrak
Film dokumenter "Sejauh Kumelangkah" yang ditayangkan pada Program Belajar dari Rumah Kemendikbud RI di TVRI mendapatkan somasi dari Sutradara Film tersebut atas penayangan, modifikasi dan mutilasi tanpa sepengetahuan dan izin dari pencipta atau pemegang hak cipta film. Rumusan masalah penulisan ini yaitu apa saja bentuk-bentuk pelanggaran hak cipta yang dilakukan oleh Kemendikbud, dan bagaimana langkah-langkah hukum yang dapat dilakukan apabila terjadi pelanggaran hak cipta oleh lembaga pemerintah. Penelitian ini merupakan penelitian hukum yuridis-normatif, dengan pendekatan perundang-undangan, pendekatan konseptual, dan pendekatan kasus yang dilakukan dengan menelaah peraturan perundang-undangan dan regulasi yang bersangkut paut dengan isu hukum. Berdasarkan hasil penelitian, penayangan film Sejauh Kumelangkah tanpa sepengetahuan, izin maupun lisensi dari pemegang hak cipta film tersebut, selain itu juga melanggar hak moral dan hak ekonomi hingga merugikan kehormatan dirinya. Langkah preventif adalah dengan memahami semua aturan yang berkaitan dengan hak cipta, atau sekurang-kurangnya mendapatkan izin lisensi secara tertulis yang telah didaftarkan di DJKI. Langkah-langkah hukum bila terjadi pelanggaran hak cipta, dengan membuat aduan baik perdata maupun pidana kepada DJKI dan/atau Kepolisian agar difasilitasi mediasi, atau melalui penyelesaian sengketa secara Arbitrase atau dengan mengajukan gugatan ganti rugi ke Pengadilan Niaga.
\end{abstract}

Kata kunci: pelanggaran hak cipta; pemerintah; lisensi; perjanjian.

\begin{abstract}
The broadcast of "How Far I'll Go" documentary on TVRI as part of the 'Learn from Home' Program by the Ministry of Education and Culture received a legal notice from the film director regarding the broadcast, modification, and mutilation without prior consent and permission from neither the creators nor copyright holders of the film. The problems in this research: the forms of copyright infringement committed by the Ministry of Education and Culture, and legal steps to be taken in case of copyright infringement by government agencies. This research is juridical-normative legal research with a statutory approach, conceptual approach, and case approach by examining laws and regulations relevant to legal issues. The research concludes that broadcasting "How Far I'll Go" film without prior consent, permission, or license from the film's copyright holders. The broadcast also violates moral and economic rights leading to the detriment of their honour. Preventive steps are to understand all regulations on the copyright or obtain a written license registered in DGIP. The legal steps are filing complaints, either civil or criminal, to DGIP and or Police to reach a mediation process or dispute resolution by Arbitration or filing a claim for compensation to the Commercial Court.
\end{abstract}

Keywords: copyright infringement; government; license; agreement. 


\section{PENDAHULUAN}

\section{Latar Belakang}

Penulisan ini dilandasi oleh permasalahan tentang apa saja bentuk-bentuk pelanggaran hak cipta, bagaimana seharusnya langkah preventif agar pemilik hak cipta maupun pemegang perjanjian lisensi dapat mencegah terjadinya suatu pelanggaran terhadap dirinya, maupun langkah-langkah hukum yang dapat dilakukan oleh pemegang hak cipta atau pemegang lisensi apabila haknya dilanggar.

Kajian ini menjadi menarik setelah adanya kasus penayangan film dokumenter yang berjudul "Sejauh Kumelangkah" yang diproduseri dan disutradarai oleh Ucu Agustin. ${ }^{1}$ Penayangan film dokumenter tersebut ditayangkan di TVRI pada program Belajar dari Rumah (BDR), merupakan Program yang baru diluncurkan oleh Kementerian Pendidikan dan Kebudayaan pada 9 April 2020 di tengah masa Pandemi Covid-19. ${ }^{2}$

Pada siaran persnya disampaikan bahwa konten atau materi pembelajaran yang disajikan berfokus pada peningkatan literasi, numerasi, serta penumbuhan karakter peserta didik. Terlepas dari tujuan mulianya tersebut, terdapat sebuah kesalahan yang dilakukan oleh Kementerian Pendidikan dan Kebudayaan yang sangat disayangkan berbagai pihak, yaitu penayangan film dokumenter "Sejauh Kumelangkah" tanpa sepengetahuan dan seizin dari pemilik dan pemegang hak cipta film tersebut. Disampaikan oleh kuasa hukum Ucu bahwa pelanggaran bermula ketika salah

Infoscreening.co, "Minikino \& Sutradara Ucu Agustin Luncurkan Film 'Sejauh Kumelangkah' Versi Inklusif," Infoscreening. Co 17 November 2020, last modified 2020, accessed December 13, 2020, https://infoscreening.co/peluncuran-film-sejauhkumelangkah-versi-inklusif/.

2 Pengelola Web Kemdikbud, "Perluas Akses Belajar Di Masa Covid-19, Mendikbud Luncurkan Program Belajar Dari Rumah," Siaran Pers Nomor:083/Sipres/A6/IV/2020, last modified 2020, accessed December 14, 2020, https://www.kemdikbud.go.id/main/blog/2020/04/perl uas-akses-belajar-di-masa-covid19-mendikbud-

luncurkan-program-belajar-dari-

rumah\#: :text=\%22Program Belajar dari Rumah mulai,selama 3 bulan ke depan.; "Peluncuran Program: 'Belajar Dari Rumah," Kemdikbud RI Youtube Channel, last modified 2020, accessed December 13, 2020, https://www.youtube.com/watch?v=21axUkEQhOQ. seorang staf ahli di Kemendikbud meminta InDocs (Yayasan Masyarakat Mandiri Film Indonesia) untuk merekomendasikan film dokumenter Indonesia untuk ditayangkan program BDR Kemendikbud di TVRI. In-Docs telah meminta draft kontrak atau MoU supaya semua pihak secara transparan dapat mengetahui skema kerjasama penayangan film dokumenter tersebut, tetapi tidak ada tanggapan dari Kemendikbud. ${ }^{3}$

Film dokumenter ini dikabarkan telah berkontrak dengan Aljazeera Internasional (AJIMalaysia) yang mengharuskan film dokumenter tersebut ditayangkan perdana di platform TV AI Jazeera, eksklusif dengan masa hold back enam bulan. Namun, tiba-tiba tanpa sepengetahuan pemilik dan pemegang hak cipta, film dokumenter tersebut ditayangkan di TVRI pada program BDR Kemendikbud dan juga disiarkan di UseeTV pada 25 Juni 2020, tanpa kontrak, tanpa izin, dan tanpa pemberitahuan kepada In-Docs dan Ucu Agustin. ${ }^{4}$

3 "Disomasi Sutradara Film 'Sejauh Kumelangkah', Ini Respon Kemendikbud," Tribunnews.Com 5 Oktober 2020, last modified 2020, accessed December 13, 2020 ,

https://www.tribunnews.com/nasional/2020/10/05/diso masi-sutradara-film-sejauh-kumelangkah-ini-responkemendikbud?page $=2$.

4 CNN Indonesia, "Kemendikbud Minta Maaf Ke Sutradara Film Sejauh Kumelangkah," 10 Oktober 2020, last modified 2020, accessed December 13, 2020 ,

https://www.cnnindonesia.com/nasional/20201010105 047-20-556788/kemendikbud-minta-maaf-kesutradara-film-sejauh-kumelangkah; CNN Indonesia, “Sutradara 'Sejauh Ku Melangkah' Tolak Maaf Kemendikbud," 13 Oktober 2020, last modified 2020, accessed December 13, 2020, https://www.cnnindonesia.com/nasional/20201013141 155-12-557867/sutradara-sejauh-ku-melangkah-tolakmaaf-kemendikbud; Riyan Setiawan, "Sutradara Film Sejauh Melangkah Tak Puas Jawaban Kemendikbud \& TVRI," Tirto. ID 13 Oktober 2020, last modified 2020, accessed December 13, 2020, https://tirto.id/sutradara-film-sejauh-melangkah-takpuas-jawaban-kemendikbud-tvri-f5SY; Bangun Santoso and Stephanus Randitio, "Disomasi Langgar Hak Cipta FIlm Sejauh Kumelangkah, Ini Reaksi Kemendikbud," Suara.Com 05 Oktober 2020, last modified

2020 , https://www.suara.com/news/2020/10/05/102712/diso masi-langgar-hak-cipta-film-sejauh-kumelangkah-inireaksi-kemendikbud; Rifan Aditya and Farah Nabila, "TVRI Tayangkan Film Sejauh Kumelangkah Tanpa Izin, Kemendikbud Minta Maaf," Suara.Com 10 
Film dokumenter "Sejauh Kumelangkah" tidak hanya diberi logo Kemendikbud dan TVRI, akan tetapi juga dimutilasi dan dimodifikasi sedemikian rupa sehingga pesan dalam film mengenai isu disabilitas netra banyak yang terpotong-potong, hilang dan tidak tersampaikan dengan baik. ${ }^{5}$ Kesalahan lainnya juga adalah Kemendikbud secara sepihak mengirim uang sebesar Rp 1,5 juta kepada InDocs melalui rekening atas nama pribadi/perorangan dan bukan melalui rekening resmi institusi Kemendikbud. ${ }^{6}$

Pada 6 Juli 2020 Kemendikbud mengeluarkan surat permintaan maaf secara resmi dan membantu menurunkan film Sejauh Kumelangkah dari Usee TV. Selanjutnya pada 10 dan 18 Agustus 2020 disampaikan bahwa pihak Kemendikbud telah hadir pada mediasi dengan kuasa hukum Ucu Agustin.

Pada 2 Oktober 2020, Ucu Agustin melalui kuasa hukumnya melayangkan somasi kepada Kemedikbud, TVRI dan Usee TV milik PT. Telkom. Dalam somasinya, ketiga institusi pemerintah (Kemendikbud, TVRI dan UseeTV PT. Telkom) telah melakukan perbuatan melawan hukum, yaitu pelanggaran hak cipta yang tercantum pada Pasal 5 Ayat (1) huruf e, Pasal 9 Ayat (1) huruf $c$ dan d, dan Pasal 113 Ayat (2) Undang-Undang Nomor 28 Tahun 2014 tentang Hak Cipta serta Pasal 7 Ayat (1) dan Pasal 52 Undang-Undang Nomor 14 Tahun 2008 tentang Keterbukaan Informasi Publik. Ganti rugi yang dimintakan secara tanggung renteng sebesar USD $\$ 80.000$ atau sekitar Rp. 1.190.391.312 (kurs 1USD = 14.879 IDR), selain itu Kemendikbud, TVRI dan Telkom juga dituntut untuk meminta maaf secara terbuka ke publik karena telah melanggar hak cipta dengan menggunakan uang rakyat untuk mitigasi pandemi Covid-19. ${ }^{7}$

Oktober 2020, last modified 2020, accessed December 13 , 2020 , https://www.suara.com/news/2020/10/10/132044/tvritayangkan-film-sejauh-kumelangkah-tanpa-izin-

kemendikbud-minta-maaf?page=all; "Disomasi Sutradara Film 'Sejauh Kumelangkah', Ini Respon Kemendikbud."

5 Santoso and Randitio, "Disomasi Langgar Hak Cipta FIlm Sejauh Kumelangkah, Ini Reaksi Kemendikbud."

6 "Disomasi Sutradara Ilm Sejauh Kumelangkah, Kemendikbud Akui Lakukan Kesalahan," DW Made For Minds, 5 Oktober 2020.

7 Santoso and Randitio, "Disomasi Langgar Hak Cipta FIlm Sejauh Kumelangkah, Ini Reaksi Kemendikbud"; "Disomasi Sutradara Ilm Sejauh Kumelangkah, Kemendikbud Akui Lakukan Kesalahan.”
Hingga sampai penulisan ini dibuat, belum ada kelanjutan kasus tersebut.

\section{Rumusan Masalah}

Berdasarkan paparan latar belakang di atas, maka rumusan masalah dalam penelitian ini adalah

1. Apa saja bentuk-bentuk pelanggaran hak cipta yang dilakukan oleh Kementerian Pendidikan dan Kebudayaan?

2. Bagaimana penyelesaian sengketa hak cipta yang dapat dilakukan apabila terjadi pelanggaran hak cipta?

\section{Tujuan}

\section{Penulisan ini bertujuan untuk}

1. Menganalisis bentuk-bentuk pelanggaran hak cipta yang dilakukan oleh Kementerian Pendidikan dan Kebudayaan;

2. Mengetahui dan memahami langkah-langkah hukum bila terjadi pelanggaran hak cipta

\section{Metode Penelitian}

\section{Tipe Pendekatan}

Penelitian ini merupakan penelitian hukum yuridis-normatif, dengan pendekatan perundang-undangan (statute approach), pendekatan konseptual (conceptual approach), dan pendekatan kasus ${ }^{8}$ (case approach) yang dilakukan dengan menelaah peraturan perundang-undangan dan regulasi yang bersangkut paut dengan isu hukum ${ }^{9}$ yang telah diuraikan pada latar belakang di atas. Bahan hukum sebagai rujukan dalam kajian ini berupa bahan hukum primer dan bahan hukum sekunder. Bahan hukum primer terdiri dari peraturan perundangundangan: Burgelijk Wetboek (BW), UndangUndang Nomor 28 Tahun 2014 tentang Hak Cipta, dan Peraturan Pemerintah Nomor 36 Tahun 2018 tentang Pencatatan Perjanjian Lisensi Kekayaan Intelektual, sedangkan bahan hukum sekunder terdiri dari doktrin, jurnal, serta sumber-sumber lain yang berkaitan dengan hak cipta.

Case studies, in their true essence, explore and case study as a research method 2 investigate contemporary real-life phenomenon through detailed contextual analysis of a limited number of events or conditions, and their relationships

Zaidah Zainal, "Case Study as A Research Method," Jurnal Kemanusiaan Vol. 5 No. (2007).

9 Peter Mahmud Marzuki, Penelitian Hukum, revisi. (Jakarta: Kencana - Prenada Media Group, 2005). h. 133 


\section{Metode Pengumpulan Data}

Bahan hukum primer dan sekunder diinventaris, kemudian diidentifikasi dianalisis dengan contoh kasus penayangan film 'Sejauh Kumelangkah'.

\section{Teknik Analisa Data}

Teknik Analisis bahan hukum menggunakan teknik deskriptif, evaluatif, dan argumentatif. Teknik deskriptif analitis ini disusun secara kualitatif untuk dapat menggambarkan permasalahan yang diangkat secara jelas.

\section{PEMBAHASAN}

Artikel ini akan diulas dalam beberapa subbab yang diawali dengan pembahasan konseptual, yang dispesifikkan pada landasan hukum perlindungan hak cipta di Indonesia, tinjauan umum terkait perjanjian dan perjanjian lisensi. Setelahnya pembahasan untuk menjawab rumusan masalah pada artikel ini.

\section{Landasan Hukum Pelindungan Hak Cipta di Indonesia}

Hak kekayaan Intelektual (HKI) atau Intellectual Property Right (IPR) adalah aset berharga yang bersifat nonkebendaan (immaterial) yang merupakan kreativitas manusia yang menghasilkan karya-karya inovatif yang dapat diterapkan dalam kehidupan manusia. ${ }^{10}$ Kreativitas adalah daya cipta manusia di bidang ilmu pengetahuan, seni, dan sastra yang dilindungi hak cipta. Sedangkan inovasi adalah hasil penemuan manusia di bidang teknologi dan desain yang dilindungi Hak Kekayaan Industri (Hak Paten, Merek, Desain Industri, Desain Tata Letai Sirkuit Terpadu, Rahasia Dagang, dan Perlindungan Varietas Tanaman). ${ }^{11}$

Indonesia telah menjadi anggota berbagai perjanjian internasional di bidang hak cipta dan hak terkait sehingga dibentuklah Undang-

10 Imas Rosidawati Wiradirja and Fontian Munzil, Pengetahuan Tradisional \& Kekayaan Intelektual: Perlindungan Pengetahuan Tradisional Berdasarkan Asas Keadilan Melalui Sui Generis Intellectual Property System (Bandung: PT Refika Aditama, 2018). h.42

11 Iswi Hariyani and dkk, Buku Pintar HAKI Dan Warisan Budaya (Yogyakarta: UGM Press, 2018); R. Serfianto D. Purnomo Iswi Haryani, Cita Yustisia Serfiyani et al., Hak Kekayaan Intelektual Sebagai Jaminan Kredit, ed. Dwi Prabantini, I. (Yogyakarta: ANDI, 2018). h.19
Undang nasional tentang Hak Cipta. ${ }^{12}$ Saat ini Undang-Undang tentang Hak cipta yang berlaku adalah Undang-Undang Nomor 28 tahun 2014 (selanjutnya disingkat UU HC 28/2014).

Definisi hak cipta terdapat dalam Pasal 1 Ayat (1) UU HC 28/2014, berbunyi, 'Hak cipta adalah hak eksklusif pencipta yang timbul secara otomatis berdasarkan prinsip deklaratif setelah suatu ciptaan diwujudkan dalam bentuk nyata tanpa mengurangi pembatasan sesuai dengan ketentuan peraturan perundangundangan'. Yang dimaksud dengan 'hak eksklusif' adalah hak yang hanya diperuntukkan bagi Pencipta, sehingga tidak ada pihak lain yang dapat memanfaatkan hak tersebut tanpa izin Pencipta. Pemegang Hak Cipta yang bukan Pencipta hanya memiliki sebagian dari hak eksklusif berupa hak ekonomi. ${ }^{13}$

Secara garis besar Hak Cipta dalam UU HC 28/2014 mengatur pelindungan Hak Cipta dilakukan dengan waktu yang lebih panjang sejalan dengan penerapan aturan di berbagai negara sehingga jangka waktu pelindungan Hak Cipta di bidang tertentu diberlakukan selama hidup pencipta ditambah 70 (tujuh puluh) tahun setelah Pencipta meninggal dunia. Pelindungan lainnya yang terkait hak ekonomi para Pencipta dan/atau Pemilik Hak Terkait, termasuk membatasi pengalihan hak ekonomi dalam bentuk jual putus (sold flat). ${ }^{14}$ Yang dimaksud dengan "jual putus" adalah perjanjian yang mengharuskan Pencipta menyerahkan Ciptaannya melalui pembayaran lunas oleh pihak pembeli sehingga hak ekonomi atas Ciptaan tersebut beralih seluruhnya kepada pembeli tanpa batas waktu, atau dalam praktik dikenal dengan istilah sold flat. ${ }^{15}$

Jenis Ciptaan yang diperbolehkan yaitu, Karya Tulis, Karya Seni, Komposisi Musik, Karya Audio Visual, Karya Fotografi, Karya Drama dan Koreografi, Karya Rekaman dan Karya Lainnya. Film dokumenter merupakan

12 Lihat konsideran menimbang huruf c, Presiden RI, Undang-Undang Republik Indonesia Nomor 28 Tahun 2014 Tentang Hak Cipta (Indonesia, 2014).

13 Penjelasan Pasal 4 Undang-Undang Republik Indonesia Nomor 28 Tahun 2014 tentang Hak Cipta

14 Lihat Penjelasan Bagian I Umum, huruf $a$ dan $b$ Undang-Undang Republik Indonesia Nomor 28 Tahun 2014 tentang Hak Cipta

15 Lihat Penjelasan Pasal 18 Undang-Undang Republik Indonesia Nomor 28 Tahun 2014 tentang Hak Cipta 
sub jenis ciptaan yang masuk dalam kategori Karya Audio Visual. ${ }^{16}$

Sejak reformasi, bidang usaha perfilman dapat dimasuki siapapun sepanjang mengurus perizinan sesuai peruntukannya. Secara rinci, bidang usaha perfilman meliputi kegiatan: ${ }^{17}$

- Pembuatan film;

- Jasa teknik film;

- Ekspor film;

- Impor film seluloid;

- Impor rekaman video;

- Pengedaran film seluloid impor;

- Pengedaran rekaman video impor;

- Pengedaran film Indonesia;

- Pertunjukan film;

- Penayangan film.

Hak Cipta sebagaimana dimaksud dalam UU HC 28/2014 merupakan Hak Eksklusif yang terdiri dari Hak Moral dan Hak Ekonomi. ${ }^{18}$ Hak Moral melekat secara pribadi pada diri Pencipta, tidak dapat dialihkan selama Pencipta masih hidup tetapi dapat pelaksanaan hak tersebut dapat dialihkan dengan wasiat atau sebab lain setelah Pencipta meninggal dunia. Terkait hak yang melekat abadi pada diri Pencipta, Pencipta dapat tetap mencantumkan atau tidak mencantumkan namanya sehubungan dengan Pemakaian Ciptaan untuk umum, menggunakan nama aliasnya atau nama samarannya, mengubah ciptaannya sesuai dengan kepatutan, mengubah judul atau anak judul ciptaan, dan mempertahankan haknya dalam hal terjadi distorsi ciptaan, mutilasi ciptaan, modifikasi ciptaan, atau hal yang bersifat merugikan kehormatan diri atau reputasinya. ${ }^{19}$ Untuk melindungi hak moral, Pencipta dapat memiliki informasi manajemen Hak Cipta dan/atau informasi elektronik Hak Cipta. ${ }^{20}$

Dalam penjelasan Pasal 5 huruf e UU HC 28/2014 dijelaskan maksud dari "distorsi

16 "Manual Book Aplikasi E-HakCipta," in Manual EBook (Jakarta: Direktorat Teknologi Informasi, Direktorat Jenderal Kekayaan Intelektual, n.d.).

17 Agus Wasita, "Perlindungan Hukum Pemegang Hak Cipta Atas Film Impor," Jurnal BECOSS (Business Economic, Communication, and Social Sciences 2, no. No. 2 (2020): 1-12, https://journal.binus.ac.id/index.php/BECOSS/article/ view/6132/3827.

18 Lihat Pasal 4 Undang-Undang Republik Indonesia Nomor 28 Tahun 2014 tentang Hak Cipta

19 Lebih lanjut lihat Pasal 5 Undang-Undang Republik Indonesia Nomor 28 Tahun 2014 tentang Hak Cipta

20 Lihat Pasal 6 Undang-Undang Republik Indonesia Nomor 28 Tahun 2014 tentang Hak Cipta
Ciptaan" adalah tindakan pemutarbalikan suatu fakta atau identitas Ciptaan, "mutilasi ciptaan" adalah proses atau tindakan menghilangkan sebagian ciptaan, sedangkan "modifikasi Ciptaan" adalah pengubahan atas ciptaan.

Pencipta atau Pemegang Hak Cipta memiliki hak ekonomi untuk melakukan (i) penerbitan Ciptaan; (ii) penggandaan Ciptaan dalam segala bentuknya; (iii) penerjemahan Ciptaan; (iv) pengadaptasian, pengaransemenan, atau pentransformasian Ciptaan; (v) pendistribusian Ciptaan atau salinannya; (vi) pertunjukan Ciptaan; (vii) pengumuman Ciptaan; (viii) komunikasi Ciptaan; dan (ix) penyewaan Ciptaan. ${ }^{21}$

Dalam UU HC 28/2014 juga mengatur terkait Ganti Rugi, baik dalam perkara perdata atau pidana yang dibebankan kepada pelaku pelanggaran hak ekonomi Pencipta, Pemegang Hak Cipta dan/atau pemilik Hak Terkait berdasarkan putusan pengadilan yang berkekuatan hukum tetap. ${ }^{22}$ Pencipta, pemegang Hak Clpta dan/atau pemegang Hak Terkait atau ahli warisnya yang mengalami kerugian ekonomi berhak memperoleh Ganti Rugi. Ganti Rugi yang dimaksud diberikan dan dicantumkan sekaligus dalam amar putusan pengadilan tentang perkara tindak pidana Hak Cipta dan/atau Hak terkait. Ganti Rugi dibayarkan paling lama 6 (enam) bulan setelah putusan pengadilan yang berkekuatan hukum tetap..$^{23}$

Pada hakekatnya, hak ekonomi pemegang hak cipta dikaitkan dengan perjanjian yang disepakati oleh para pihak, sehingga diperlukan juga pemahaman terkait perjanjian secara umum maupun bentuk perjanjian lisensi untuk mendapatkan hak tayang, ataupun hak lainnya sebagaimana disebutkan dalam Pasal 9 UUHC 28/2014 yang sudah disebutkan di atas.

\section{Tinjauan Umum tentang Perjanjian}

Rumusan Pasal 1313 Burgelijk Wetboek $(B W)^{24}$ tentang 'kontrak atau perjanjian' yaitu 'suatu perjanjian adalah suatu perbuatan dengan mana satu orang atau lebih

21 Lebih lanjut lihat Pasal 9 Undang-Undang Republik Indonesia Nomor 28 Tahun 2014 tentang Hak Cipta

22 Lihat Pasal 1 angka 25 Undang-Undang Republik Indonesia Nomor 28 Tahun 2014 tentang Hak Cipta

23 Lihat Pasal 96 Undang-Undang Republik Indonesia Nomor 28 Tahun 2014 tentang Hak Cipta

24 Terjemahan BW dalam bahasa Indonesia R. Subekti and R. Tjitrosudibio, Burgerlijk Wetboek $(B W)$, n.d. 
mengikatkan dirinya terhadap satu orang lain atau lebih. Definisi pada Pasal 1313 BW tersebut oleh para Sarjana Hukum dianggap kurang tepat dan sangat luas, sehingga memiliki kelemahan. Diantaranya hanya menyangkut perjanjian sepihak, makna 'perbuatan' pada Pasal tersebut sangat luas, dapat menimbulkan akibat hukum tanpa dimaksudkan. ${ }^{25}$

Definisi Pasal 1313 BW telah mengalami perubahan dalam Nieuw Burgelijk Wetboek (NBW), sebagaimana diatur di dalam Buku 6 Bab 5 Pasal 6:213, yaitu: 'a contract in the sense of this title is a multilateral juridical act whereby one or more parties assume an obligationtowards one or more other parties ${ }^{26}$

Buku III BW tentang Perikatan (van Verbintenis) tidak memberikan definisi tentang apa yang dimaksud dengan perikatan itu. Namun diawali dengan Pasal 1233 BW mengenai sumber perikatan, yaitu kontrak atau perjanjian dan undang-undang. ${ }^{27}$ Terdapat empat unsur perikatan, yaitu: ${ }^{28}$

1. Hubungan hukum, artinya perikatan yang dimaksud adalah bentuk hukum yang menimbulkan akibat hukum;

2. Bersifat harta benda, artinya, hubungan yang terjalin di antara para pihak berorientasi pada harta kekayaan (keuntungan);

3. Para pihak, artinya dalam hubungan hukum tersebut melibatkan pihak-pihak sebagai subjek hukum;

4. Prestasi, artinya hubungan hukum tersebut melahirkan kewajiban-kewajiban (prestasi) kepada para pihaknya (prestasi-kontraprestasi), yang pada kondisi tertentu dapat

25 Setiawan, Pokok-Pokok Hukum Perikatan, Cet. IV. (Jakarta: Binacipta, 1987); R.M. Suryoningrat, AsasAsas Hukum Perikatan (Bandung: Tarsito, 1985); Purwahid Patrik, Dasar-Dasar Hukum Perikatan (Bandung: Mandar Maju, 1994); Agus Yudha Hernoko, Hukum Perjanjian: Asas Proporsionalitas Kontrak Komersial, Pertama. (Jakarta: Kencana Prenada Media Group, 2010); I Gusti Bagus Arya Anggara Paramarta, "Akibat Hukum Perjanjian Lisensi Terhadap Pihak Ketiga," Acta Comitas I (2007): 75-83.

26 P.P.C Haanapel and Ejaan Mackaay, Nieuw Nederlands Burgelijk Wetboek (Het Vermogensrecht) (Deventer: Kluwer Law and Taxation Publisher, 1990); Hernoko, Hukum Perjanjian: Asas Proporsionalitas Kontrak Komersial. h.18

27 Hernoko, Hukum Perjanjian: Asas Proporsionalitas Kontrak Komersial. h.19

28 Ibid. h. 20 dipaksakan pemenuhannya, bahkan apabila diperlukan menggunakan alat negara.

Pelaksanaan perjanjian adalah realisasi atau pemenuhan hak dan kewajiban yang telah diperjanjikan oleh para pihak yang membuat perjanjian tersebut. ${ }^{29}$ Pada dasarnya hal yang dijanjikan untuk dilaksanakan dalam suatu perjanjian dibagi dalam 3 jenis, yaitu: ${ }^{30}$

1. Perjanjian untuk memberikan suatu barang/benda;

2. Perjanjian untuk berbuat sesuatu; dan

3. Perjanjian untuk tidak berbuat sesuatu

Buku II Pasal 1320 BW, mengatur mengenai keabsahan perjanjian. Pertama, syarat kesepakatan atau kecakapan, merupakan unsur subjektif karena berkenaan dengan diri orang atau subjek yang membuat perjanjian. Kedua, syarat objek tertentu atau kausa yang diperbolehkan merupakan unsur objektif. ${ }^{31}$ Perjanjian yang tidak memenuhi persyaratan sebagaimana yang diatur dalam Pasal 1320 BW, mempunyai akibat-akibat sebagai berikut: ${ }^{32}$

1. 'Noneksistensi', apabila tidak ada kesepakatan maka tidak timbul kontrak (perjanjian);

2. Vernietigbaar atau dapat dibatalkan, apabila perjanjian tersebut lahir karena adanya cacat kehendak (wilsgebreke) atau karena ketidakcakapan (onbekwaamheid) - (Pasal 1320 BW syarat 1 dan 2), maka diartikan hal ini berkaitan dengan unsur subjektif, sehingga akibat hukumnya terhadap perjanjian tersebut adalah dapat dibatalkan; dan

3. Nietig atau batal demi hukum, apabila perjanjian tidak memenuhi syarat objek tertentu atau tidak ada kausa, tidak diperbolehkan (Pasal 1320 BW syarat 3 dan 4), maka hal ini berkaitan dengan unsur obyektif, sehingga akibat kontrak tersebut batal demi hukum.

29 Paramarta, "Akibat Hukum Perjanjian Lisensi Terhadap Pihak Ketiga."

30 P.N.H Simanjuntak, Pokok-Pokok Hukum Perdata Indonesia (Jakarta: Ikrar Mandiri Abadi, 2005). h. 337

31 Hernoko, Hukum Perjanjian: Asas Proporsionalitas Kontrak Komersial. h. 160

32 J.H. Niewenhuis, Pokok-Pokok Hukum Perikatan, ed. Terjemahan Djasadin Saragih (Surabaya, 1985); Hernoko, Hukum Perjanjian: Asas Proporsionalitas Kontrak Komersial. h. 160 
Asas-asas umum dalam perjanjian, sekurangkurangnya terdapat 4 asas yang dianggap saka guru hukum perjanjian, yaitu: ${ }^{33}$

1. Asas kebebasan berkontrak;

Asas kebebasan berkontrak merupakan perwujudan dari kehendak bebas, pancaran hak asasi manusia. Buku III BW menganut sistem terbuka, artinya hukum memberi keleluasan kepada para pihak untuk mengatur pola hubungan hukumnya. Sistem terbuka Buku III BW tercermin dari substansi Pasal 1338 Ayat (1) BW yang menyatakan bahwa 'semua perjanjian yang dibuat secara sah berlaku sebagai undang-undang bagi mereka yang membuatnya. Menurut Subekti ${ }^{34}$, cara menyimpulkan asas kebebasan berkontrak adalah dengan menekankan pada perkataan "semua" yang ada di muka perkataan "perjanjian". Istilah "semua" di dalamnya terkandung asas partij autonomic; freedom of contract; beginsel van de contract vrijheid - sepenuhnya diserahkan kepada para pihak mengenai isi maupun bentuk perjanjian yang akan dibuat, termasuk penuangan dalam kontrak standard. ${ }^{35}$

Asas kebebasan hukum berkontrak dalam hukum perjanjian Indonesia meliputi ruang lingkup sebagai berikut: ${ }^{36}$

a. Kebebasan untuk membuat atau tidak membuat perjanjian;

b. Kebebasan untuk memilih pihak dengan siapa ia ingin membuat perjanjian;

c. Kebebasan untuk menentukan atau memilih kausa dari perjanjian yang akan dibuat;

d. Kebebasan untuk menentukan objek perjanjian;

e. Kebebasan untuk menentukan bentuk suatu perjanjian;

f. Kebebasan untuk menerima atau menyimpang dari ketentuan undang-

33 Hernoko, Hukum Perjanjian: Asas Proporsionalitas Kontrak Komersial. h. 107

34 Subekti, Aneka Perjanjian, Cet. Keena. (Bandung: Alumni, 1995); Hernoko, Hukum Perjanjian: Asas Proporsionalitas Kontrak Komersial. h. 109

35 John P. Dawson, Contracts (Case and Comment) (New York: The Foundation Press, 1982); Hernoko, Hukum Perjanjian: Asas Proporsionalitas Kontrak Komersial. h. 110

36 Sutan Remi Sjahdeini, Kebebasan Berkontrak Dan Perlindungan Yang Seimbang Bagi Para Pihak Dalam Perjanjian Kredit Bank Di Indonesia (Jakarta: Institut Bankir Indonesia, 1993); Hernoko, Hukum Perjanjian: Asas Proporsionalitas Kontrak Komersial. undang yang bersifat opsional (aanvullend, optional).

2. Asas konsensualisme;

Pasal 1320 BW mengandung asas esensial, yaitu asas konsensualisme yang menentukan "ada"-nya perjanjian (raison d'etre, hert bestaanwarde). Dalam asa ini para pihak saling mengikatkan diri dan menimbulkan kepercayaan (vertrouwen) di antara para pihak terhadap pemenuhan perjanjian. Asas kepercayaan (vertrowenleer) bersumber dari moral. ${ }^{37}$

Dalam BW cacat kehendak meliputi 3 hal, yaitu:
a. Kesesatan atau dwaling;
b. Penipuan atau bedrog;
c. Paksaan atau dwang.

3. Asas pacta sunt servanda;

Kekuatan mengikat kontrak pada prinsipnya memiliki daya kerja (strekking) sebatas para pihak yang membuatnya. Hal ini menunjukan bahwa hak yang lahir merupakan hak perorangan (personlijk) dan bersifat relatif. ${ }^{38}$

4. Asas Iktikad baik.

Perjanjian berdasarkan Iktikad baik (contractus bonafidei) terdapat dalam rumusan Pasal 1338 Ayat (3) BW, yang berbunyi "perjanjian-perjanjian harus dilaksanakan dengan iktikad baik". Maksudnya perjanjian ini dilaksanakan menurut kepatutan dan keadilan. Menurut J.M. van Dunne, ${ }^{39}$ daya berlaku iktikad baik (goede trouw; good faith) meliputi seluruh proses kontrak atau diibaratkan dengan "the rise and fall of contract". Dengan demikian, itikad baik meliputi tiga fase perjalanan kontrak, yaitu: (i) pre contractuele fase, (ii) contractuele fase, (iii) postcontractuele fase..$^{40}$

37 Mariam Darus Badrulzaman and Et Al, Kompilasi Hukum Perikatan (Bandung: Citra Aditya Bakti, 2001); Hernoko, Hukum Perjanjian: Asas Proporsionalitas Kontrak Komersial. h. 121

38 M. Isnaeni, Hipotek Pesawat Udara Di Indonesia (Surabaya: Dharma Muda, 1996); Hernoko, Hukum Perjanjian: Asas Proporsionalitas Kontrak Komersial. h. 130

39 J.M. van Dunne, Verbintenissenrecht (Deel 1, Contractenrecht, le Gedeelte) (Kluwer-Deventer, 1993); Steven R. et al Schuit, Dutch Business Law (Antwerp-Boston-London-Frankfurt: Kluwer Kaw \& Taxation Publisher, 1983); Hernoko, Hukum Perjanjian: Asas Proporsionalitas Kontrak Komersial. h. 136

40 Steven J. Burton and Eric G. Andersen, Contractual Goodfaith (Formation, Performance, Breach, Enforcement) (Kanada: Little, Brown and Company, 


\section{Perjanjian Lisensi}

Perjanjian lisensi dalam pandangan hukum perdata, merupakan jenis perjanjian innominant yaitu jenis perjanjian yang tidak diatur atau perjanjian di luar BW. Meskipun perjanjian ini tidak diatur dalam BW, namun ketentuan-ketentuan umum dalam penyusunan dan pelaksanaan perjanjian lisensi berlaku prinsip umum perjanjian dalam BW. ${ }^{41}$

Kata lisensi berasal dari bahasa latin, yaitu licencia, yang artinya izin atau kebebasan. Sehingga apabila seseorang diberi lisensi, maka berarti kita mengizinkan kepada orang tersebut untuk menggunakan sesuatu yang sebelumnya tidak diperbolehkan. ${ }^{42}$ Secara yuridis, lisensi diartikan sebagai suatu perjanjian antara pemberi lisensi (licencor) dan penerima lisensi (licencee), di mana licencor dengan pembayaran dan kondisi tertentu memberikan izin kepada licensee untuk menggunakan hak atas kekayaan intelektualnya (intellectual property rights) untuk memproduksi, mendistribusikan, dan memasarkan produk-produk mliki licensor, dan sebagai imbalannya licensor mendapatkan royalti dari licensee..$^{43}$

Pada Pasal 1 angka 20 UU HC 28/2014 menyebutkan bahwa "Lisensi adalah izin tertulis yang diberikan oleh Pemegang Hak Cipta atau Pemilik Hak Terkait kepada pihak lain untuk melaksanakan hak ekonomi atas Ciptaannya atau produk Hak Terkait dengan syarat tertentu." Di sini secara tegas undang-undang telah menyebutkan bahwa lisensi yang diberikan oleh Pemegang Hak Cipta atau Pemilik Hak Terkait adalah dengan bentuk tertulis, sehingga dapat diartikan bahwa lisensi

1995); Hernoko, Hukum Perjanjian: Asas Proporsionalitas Kontrak Komersial. ibid

41 Retna Gumanti, "Perjanjian Lisensi Di Indonesia," AlMizan Vol. 12 (2016): 245-260, http://journal.iaingorontalo.ac.id/index.php/am.

42 C.S.T Kansil, Hak Milik Intelektual (Jakarta: Bumi Aksara, 1990). h.65

43 Soemantoro, Masalah Pengaturan Alih Teknologi (Bandung: Alumni, 1993); Christopher M. Newman, “A License Is Not a 'Contract Not to Sue': Disentangling Property and Contract in the Law of Copyright Licenses," Journal Lowa Law Review 98 (2013); Hesty D. Lestari, "Kepemilikan Hak Cipta Dalam Perjanjian Lisensi (Kajian Putusan Mahkamah Agung Nomor 104 PK/PDT.SUS/2011," Jurnal Yudisial 6, no. No. 2 (2013), https://jurnal.komisiyudisial.go.id/index.php/jy/article/ view/112. ini dituangkan dalam sebuah perjanjian yang dinamakan perjanjian lisensi.

Dalam setiap perjanjian lisensi film terdapat 5 kategori yang dijadikan dasar perjanjian lisensi, yaitu: ${ }^{44}$

\section{Basic License Terms}

Pada bagian ini memuat; judul film, wilayah peredaran, waktu lisensi, bahasa dari film terkait maksud dan yang akan diizinkan untuk digunakan. Satu perjanjian lisensi dapat memuat pembelian 2 film atau lebih dari produser yang sama, kecuali beda wilayah penayangan;

2. License Rights Terms

Bagian ini memuat tentang hak, hak apa yang diberikan produser, contohnya hak untuk penayangan di bioskop, video, televisi berlangganan, televisi teristerial dengan window time masing-masing media penayangan. Produser film dimaksud dapat memberikan haknya hanya untuk media tertentu, contoh media bioskop untuk PT. A, kemudian video untuk PT. B dan sebagainya. Namun, bisa juga seluruh hak media penayangan dipegang oleh satu perusahaan;

3. Financial Terms

Bagian ini memuat biaya minimum royalty yang harus dibayarkan, cara dan tujuan pembayaran, serta tahap pembayaran selanjutnya yang harus dipenuhi oleh perusahaan atau lembaga yang melakukan perjanjian lisensi;

4. Delivery Terms

Bagian ini merupakan syarat pengiriman barang, waktu pengiriman dan perintah pengiriman. Biasanya pengiriman barang dapat dilakukan pada saat pembayaran lisensi minimum telah lunas.

5. Additional Terms

Bagian ini biasanya memuat tentang klausul sensor, force majeure, choice of forum, penyelesaian sengketa dan sebagainya. Banyak produser film dari beberapa negara yang mempunyai hubungan bisnis dengan perusahaan menggunakan standar term and condition dari American Film Market Association, untuk menjadi acuan dalam penyelesaian sengketa antara produser dan distributor.

Perjanjian lisensi umumnya dibagi menjadi dua: 45

\footnotetext{
44 Wasita, "Perlindungan Hukum Pemegang Hak Cipta Atas Film Impor."

45 Gumanti, "Perjanjian Lisensi Di Indonesia."
} 
1. Perjanjian lisensi eksklusif, perjanjian ini menambahkan syarat lebih lanjut dari pemberi lisensi untuk tidak mengadakan perjanjian serupa dengan pihak lain manapun, atau memaksakan hak untuk menggunakan hak terkait;

2. Perjanjian lisensi non eksekutif penerima lisensi tidak mempunyai hak terhadap pihak ketiga dan penerima lisensi tidak dapat mengelak perjanjian sub lisensi. Pemilik atau pemegang hak cipta yang mengadakan perjanjian lisensi non eksklusif tetap dapat bebas memberikan atau mengadakan perjanjian lisensi dengan pihak lain.

Perjanjian lisensi dilarang memuat ketentuan yang dapat merugikan perekonomian Indonesia atau memuat ketentuan yang mengakibatkan persaingan usaha tidak sehat sebagaimana diatur dalam Undang-Undang Republik Indonesia Nomor 5 Tahun 1999 tentang Larangan Praktik Monopoli dan Persaingan Usaha Tidak Sehat. ${ }^{46}$ Begitupula aturan dalam Pasal 6 Peraturan Pemerintah Nomor 36 Tahun 2018 tentang Pencatatan Perjanjian Lisensi Kekayaan Intelektual (selanjutnya disingkat PP 36/2018 Pencatatan Perjanjian Lisensi), berbunyi:

'Perjanjian Lisensi dilarang memuat ketentuan yang dapat:

1. merugikan perekonomian Indonesia dan kepentingan nasional Indonesia;

2. memuat pembatasan yang menghambat kemampuan bangsa Indonesia dalam melakukan pengalihan, penguasaan, dan pengembangan teknologi;

3. mengakibatkan persaingan usaha tidak sehat; dan/atau

4. bertentangan dengan ketentuan peraturan perundang-undangan, nilai-nilai agama, kesusilaan, dan ketertiban umum.'

Dari konsep yang sudah dipaparkan di atas mengenai perjanjian secara umum, asas-asas dalam perjanjian dan perjanjian lisensi, maka hal tersebut dapat menjadi langkah-langkah Preventif yang dilakukan agar tidak melanggar hak cipta orang lain, maka dalam kasus ini, baiknya pihak Kementerian Pendidikan dan Kebudayaan mengevaluasi kembali para pegawai yang bekerja di bawah bagian atau bidang yang berhubungan dengan hak cipta untuk:

46 Iswi Haryani, Cita Yustisia Serfiyani et al., Hak Kekayaan Intelektual Sebagai Jaminan Kredit. h. 125
1. Lebih memahami aturan-aturan hukum yang berlaku terkait hak cipta;

2. Menjalankan kesepakatan dalam perjanjian sebagaimana yang disepakati antara para pihak, dengan memenuhi asas-asas dalam perjanjian;

3. Menjalankan perjanjian yang tidak melawan hukum atau peraturan perundang-undangan

\section{Bentuk-bentuk pelanggaran Terhadap hak Cipta}

Suatu perbuatan dapat dianggap sebagai pelanggaran hak cipta apabila mengarah pada pelanggaran hak eksklusif yang dimiliki oleh pencipta atau pemegang hak cipta. ${ }^{47}$

Bentuk pelanggaran terhadap Hak Cipta (copyright's violation) pada dasarnya berkisar pada dua hal pokok, yakni: ${ }^{48}$

1. Dengan sengaja dan tanpa hak mengumumkan, memperbanyak atau memberi izin untuk itu. Salah satu contoh pelanggaran tersebut adalah berupa dengan sengaja melanggar larangan untuk mengumumkan setiap ciptaan yang bertentangan dengan kebijaksanaan pemerintah di bidang pertahanan dan keamanan negara, kesusilaan serta ketertiban umum;

2. Dengan sengaja memamerkan, mengedarkan atau menjual kepada umum sesuatu ciptaan atau barang hasil pelanggaran Hak Cipta.

Mengenai Pengalihan Hak Cipta pada Pasal 98 Ayat (1) menyebutkan bahwa pengalihan Hak Cipta atas seluruh ciptaan kepada pihak lain mengurangi hak Pencipta atau ahli warisnya untuk menggugat setiap orang yang dengan sengaja dan tanpa hak dan tanpa persetujuan Pencipta yang melanggar hak moral Pencipta sebagaimana dimaksud dalam Pasal 5 ayat (1) UU HC 28/2014 yaitu:

1. Tetap mencantumkan atau tidak mencantumkan namanya pada salinan sehubungan dengan pemakaian Ciptaannya untuk umum;

47 Sudaryat, Sudjana, and Rika Ratna Permata, Hak Kekayaan Intelektual: Memahami Prinsip Dasar, Cakupan, Dan Undang-Undang Yang Berlaku (Bandung: Oase Media, 2010). h. 52

48 Muhamad Djumhana, R. Djubaedillah, and R Djubaedilah Muhammad,Djumhana, Hak Milik Intelektual: Sejarah, Teori, Dan Praktiknya Di Indonesia, revisi. (Bandung: PT. Citra Aditya Bakti, 2014). h. 119 
2. Menggunakan nama aliasnya atau samarannya;

3. Mengubah Ciptaannya sesuai dengan kepatutan dalam masyarakat;

4. Mengubah judul dan anak judul Ciptaan; dan mempertahankan haknya dalam hal terjadi distorsi Ciptaan, mutilasi Ciptaan, modifikasi Ciptaan, atau hal yang bersifat merugikan kehormatan diri atau reputasinya.

Pelanggaran Hak Cipta dapat mengandung unsur keperdataan dan pidana. Dalam kaitannya dengan aspek keperdataan, maka dapat dlakukan gugatan ganti rugi. Pasal 99 UU HC 28/2014 mengatur bahwa pihak yang merasa dirugikan akibat pelanggaran ini dapat mengajukan gugatan ganti rugi kepada Pengadilan Niaga atas pelanggaran Hak Cipta atau produk Hak Terkait. Pasal 99 (Ayat 1) UUHC 28/2014 menyebutkan pihak-pihak yang dapat mengajukan gugatan ganti rugi tersebut adalah Pencipta, Pemegang Hak Cipta atau Pemilik jak Terkait.

Selanjutnya pada Pasal 99 Ayat (2) dan (3) menyebutkan bahwa pihak-pihak yang dirugikan dapat meminta Pengadilan Niaga untuk melakukan tindakan-tindakan berikut:

1. Meminta untuk menyerahkan seluruh atau sebagian penghasilan yang diperoleh dari penyelenggaraan ceramah, pertemuan ilmiah, pertunjukan atau pameran karya yang merupakan hasil pelanggaran Hak Cipta atau produk Hak Terkait;

2. Memohon putusan provisi atau putusan sela untuk:
a. Meminta penyitaan Ciptaan yang dilakukan Pengumuman atau
Penggandaan, dan/atau alat
Penggandaan yang digunakan untuk menghasilkan Ciptaan hasil pelanggaran Hak Cipta dan produk Hak terkait; dan/atau
b. Menghentikan kegiatan Pengumuman, Pendistribusian, Komunikasi, dan/atau Penggandaan Ciptaan yang merupakan hasil pelanggaran Hak Cipta dan produk Hak Terkait.

Dalam hal pengaduan dengan delik aduan (pidana), Pencipta, Pemegang Hak Cipta atau Pemilik hak Terkait dapat mengajukan aduan kepada Direktorat Jenderal Kekayaan Intelektual, Kementerian Hukum dan Hak Asasi Manusia RI dan/atau Kepolisian Negara Republik Indonesia.

Dalam hal aduan disampaikan kepada Direktorat Jenderal Kekayaan Intelektual, Pasal
110 UU HC 28/2014 menyebutkan, bahwa pejabat pegawai negeri sipil yang diberi wewenang khusus sebagai penyidik dimaksud dalam UU yang mengatur mengenai hukum acara pidana untuk melakukan penyidikan tindak pidana Hak Cipta dan Hak Terkait.

Pasal 110 (Ayat (2) menyebutkan Penyidik Pegawai Negeri Sipil (PPNS) tersebut berwenang melakukan:

1. pemeriksaan atas kebenaran laporan atau keterangan berkenaan dengan tindak pidana di bidang Hak Cipta dan Hak Terkait;

2. pemeriksaan terhadap pihak atau badan hukum yang diduga melakukan tindak pidana di bidang Hak Cipta dan Hak Terkait;

3. permintaan keterangan dan barang bukti dari pihak atau badan hukum sehubungan dengan tindak pidana di bidang Hak Cipta dan Hak Terkait;

4. pemeriksaan atas pembukuan, pencatatan, dan dokumen lain berkenaan dengan tindak pidana di bidang Hak Cipta dan Hak Terkait;

5. penggeledahan dan pemeriksaan di tempat yang diduga terdapat barang bukti, pembukuan, pencatatan, dan dokumen lain yang berkenaan dengan tindak pidana di bidang Hak Cipta dan Hak Terkait;

6. penyitaan dan/atau penghentian peredaran atas izin pengadilan terhadap bahan dan barang hasil pelanggaran yang dapat dijadikan bukti dalam perkara tindak pidana di bidang Hak Cipta dan Hak Terkait sesuai dengan Kitab Undang-Undang Hukum Acara Pidana;

7. permintaan keterangan ahli dalam melaksanakan tugas penyidikan tindak pidana di bidang Hak Cipta dan Hak Terkait;

8. permintaan bantuan kepada instansi terkait untuk melakukan penangkapan, penahanan, penetapan daftar pencarian orang, pencegahan dan penangkalan terhadap pelaku tindak pidana di bidang Hak Cipta dan Hak Terkait; dan

9. penghentian penyidikan jika tidak terdapat cukup bukti adanya tindak pidana di bidang Hak Cipta dan Hak Terkait.

Dalam melakukan penyidikan, penyidik pejabat pegawai negeri sipil dapat meminta bantuan penyidik pejabat Kepolisian Negara Republik Indonesia. Penyidik pejabat pegawai negeri sipil memberitahukan dimulainya penyidikan kepada penuntut umum dan penyidik pejabat Kepolisian Negara Republik Indonesia. Hasil penyidikan yang telah dilakukan oleh penyidik pejabat pegawai negeri sipil disampaikan kepada penuntut umum 
melalui penyidik pejabat Kepolisian Negara Republik Indonesia. Dalam hal melakukan tindakan penggeledahan dan pemeriksaan di tempat yang diduga terdapat barang bukti, pembukuan, pencatatan, dan dokumen lain yang berkenaan dengan tindak pidana di bidang Hak Cipta dan Hak Terkait, juga penyitaan dan/atau penghentian peredaran atas izin pengadilan terhadap bahan dan barang hasil pelanggaran yang dapat dijadikan bukti dalam perkara tindak pidana di bidang Hak Cipta dan Hak Terkait sesuai dengan Kitab Undang-Undang Hukum Acara Pidana, Penyidik Pegawai Negeri Sipil meminta bantuan penyidik pejabat Kepolisian Negara Republik Indonesia. ${ }^{49}$

Berdasarkan paparan konsep dan beberapa peraturan perundang-undangan, kaitannya dengan kasus penayangan film dokumenter 'Sejauh Kumelangkah' yang ditayangkan oleh Kemendikbud melalui Program Belajar dari Rumah (BDR) di TVRI, maka dapat dilihat bentuk-bentuk pelanggaran yang dilakukan Kemendikbud sebagai berikut:

1. Perlu ditelaah lebih lanjut mengenai bentuk komunikasi yang dilakukan oleh salah seorang Staf Ahli Kemendikbud tersebut, karena bila dilihat dari siaran pers yang dikemukakan pihak In-Docs maupun kuasa hukum dari Pemegang Hak Cipta film dokumenter tersebut, bahwa berkali-kali pihak In-Docs menanyakan perihal perjanjian untuk hak siar, namun tidak ada tanggapan hingga sampai pada 25 Juni 2020, film dokumenter tersebut ditayangkan tanpa ada lisensi dari Pemegang Hak Cipta. Pada tahap ini, Kemendikbud dan Pemegang Hak cipta belum ada sebuah kesepakatan maupun perjanjian lisensi terkait hak siar.

2. Perlu dikonfirmasi juga, bagaimana file film dokumenter 'Sejauh Kumelangkah' sudah berada di pihak Kemendikbud dan dapat ditayangkan pada lembaga penyiaran publik, yakni TVRI. Apakah pemegang hak cipta, melalui partnernya In-Docs telah terlebih dahulu memberikan salinan file film dokumenter tersebut sebelum adanya perjanjian lisensi lebih lanjut, atau TVRI melalui Kemendikbud mendapatkan salinan file film dokumenter tersebut dengan cara melawan hukum. Bila kemungkinan yang pertama, maka kedua pihak lalai dalam hal

49 Lihat Pasal 110 ayat (3), (4), (5), dan (6) UndangUndang Republik Indonesia Nomor 28 Tahun 2014 tentang Hak Cipta menjaga dan mendapatkan hak sesuai dengan ketentuan peraturan perundangundangan, namun bila kemungkinan kedua yang terjadi, maka Kemendikbud sebagai sebuah lembaga pemerintah telah melakukan perbuatan melawan hukum;

3. Film dokumenter "Sejauh Kumelangkah" tidak hanya diberi logo Kemendikbud dan TVRI, akan tetapi juga dimutilasi dan dimodifikasi sedemikian rupa sehingga pesan dalam film mengenai isu disabilitas netra banyak yang terpotong-potong, hilang dan tidak tersampaikan dengan baik. ${ }^{50}$

Hal ini jelas telah melanggar hak moral dan hak ekonomi Pemegang Hak Cipta, yang mana pada Pasal 5 Ayat (1) huruf e disebutkan bahwa: Hak Moral merupakan hak yang melekat secara abadi pada diri Pencipta untuk mempertahankan haknya dalam hal terjadi distorsi Ciptaan, mutilasi Ciptaan, modifikasi Ciptaan, atau hal yang bersifat merugikan kehormatan diri atau reputasinya.

Sedangkan pelanggaran terhadap Hak Ekonomi, kuasa hukum Ucu Agustin menyebutkan A (1) huruf $c$, dan d, yang mana Pasal tersebut berbunyi:

Pencipta atau Pemegang Hak Cipta memiliki hak ekonomi untuk melakukan:

c. Penerjemahan Ciptaan;

d. Pengadaptasian, pengaransemenan, atau pentransformasian Ciptaan

4. Kesalahan lainnya juga adalah Kemendikbud secara sepihak mengirim uang sebesar Rp 1,5 juta kepada In-Docs melalui rekening atas nama pribadi/perorangan dan bukan melalui rekening resmi institusi Kemendikbud. Biasanya kerja sama yang dilakukan atas nama institusi atau lembaga, maka pembayaran honornya juga akan atas nama lembaga/institusi, bukan bersifat personal, sehingga jelas dalam hal ini perlu ditindak lanjuti lebih dalam oleh institusi terkait yaitu Kementerian Pendidikan dan Kebudayaan, agar masyarakat tidak simpang siur dalam menerima informasi, dan dapat memulihkan kehormatan atas nama lembaga pemerintah.

\section{Penyelesaian Sengketa Pelanggaran Hak Cipta}

Suatu perbuatan dapat dianggap pelanggaran hak cipta apabila mengarah pada pelanggaran hak eksklusif yang dimiliki oleh

50 Santoso and Randitio, "Disomasi Langgar Hak Cipta FIlm Sejauh Kumelangkah, Ini Reaksi Kemendikbud.” 
pencipta atau pemegang hak cipta. ${ }^{51}$ Pada kasus penayangan film 'Sejauh Kumelangkah', Kementerian Pendidikan dan Kebudayaan telah melanggar hak eksklusif pemegang hak cipta film tersebut dengan cara melawan hukum, tanpa ada perjanjian lisensi dan pembayaran royalti tanpa kesepakatan dan tidak melalui jalur resmi. Merasa hak eksklusifnya dilanggar, langkah hukum yang pertama kali dilakukan oleh Sutradara film 'Sejauh Kumelangkah' sebagai pemegang hak cipta dan kuasa hukumnya mengirimkan somasi kepada Kementerian Pendidikan dan Kebudayaan yang telah melanggar hak moral sebagaimana yang disebutkan dalam Pasal 5 Ayat (1) huruf e dan hak ekonomi sebagaimana yang disebutkan dalam Pasal 9 Ayat (1) huruf $\mathrm{c}$ dan e UU HC 28/2014. Somasi yang dikirimkan oleh Ucu Agustin melalui kuasa hukumnya tidak hanya sekali, melainkan hingga tiga kali somasi disampaikan, belum juga ada titik temu yang baik diantara kedua belah pihak.

Somasi dalam Kamus Besar Bahasa Indonesia diartikan sebagai teguran untuk membayar dan sebagainya. ${ }^{52}$ Somasi sendiri merupakan terjemahan dari ingerbrekestelling, yang dalam hukum perdata diatur di dalam Pasal 1238 BW dan Pasal 1243 BW. ${ }^{53}$

Menurut Philipus M. Hadjon, penyelesaian sengketa merupakan bentuk perlindungan hukum yang represif bagi rakyat. ${ }^{54}$ Selanjutnya penyelesaian sengketa diatur dalam Pasal 95 UU HC 28/2014, yang menyebutkan bahwa penyelesaian sengketa Hak Cipta dapat dilakukan melalui alternatif penyelesaian sengketa, arbitrase atau pengadilan niaga. Dalam penjelasannya, bentuk sengketa terkait dengan Hak Cipta antara lain, sengketa berupa perbuatan melawan hukum, perjanjian lisensi, sengketa

51 Sudaryat, Sudjana, and Permata, Hak Kekayaan Intelektual: Memahami Prinsip Dasar, Cakupan, Dan Undang-Undang Yang Berlaku; Harjono et al., Hukum Acara Penyelesaian Sengketa Kekayaan Intelektual (Malang: Setara Press, 2019).

52 Kamus Besar Bahasa Indonesia (KBBI) V 0.40.0 Beta (40), Edisi Keli. (Jakarta: Badan Pengembangan Bahasa dan Perbukuan, Kementerian Pendidikan dan Kebudayaan Republik Indonesia, n.d.), kbbi.kemdikbud.go.id.

53 Subekti and Tjitrosudibio, Burgerlijk Wetboek $(B W)$.

54 Philipus M. Hadjon, Perlindungan Hukum Bagi Rakyat Di Indonesia (Surabaya: Bima Ilmu Surabaya, 1987); Qur’ani Dewi Kusumawardani, “Legal Protection for Internet Users Against Web Contents with Clickbait on Online Media," Jurnal Penelitian Hukum De Jure 19, no. 1 (2018): 11-30. mengenai tarif dalam penarikan imbalan atau royalti. Sedangkan yang dimaksud dengan "alternatif penyelesaian sengketa" adalah proses penyelesaian sengketa melalui mediasi, negosiasi, atau konsoliasi.

Alternatif penyelesaian sengketa secara negosiasi, melibatkan pihak yang berselisih yang mencari solusi terkait masalah mereka secara mandiri tanpa adanya intervensi dari pihak ketiga. ${ }^{55}$ Negosiasi merupakan metode yang paling fleksibel, informal dan langsung mengarah pada para pihak, mudah dikendalikan para pihak dan dapat disesuaikan dengan kepentingan masing-masing pihak. ${ }^{56}$ Namun bila negosiasi, langkah logis selanjutnya adalah dengan mencari bantuan pihak ketiga yang netral. Pihak ketiga membantu pihak yang berselisih untuk mencapai kesepakatan diantara keduanya, karena pihak ketiga bukan sebagai hakim atau arbiter yang memberikan solusi kepada para pihak yang bersengketa. ${ }^{57}$

Alternatif penyelesaian sengketa lainnya dapat dilakukan melalui mediasi, baik yang terlembagakan maupun ad hoc. Lembaga dan proses mediasi menurut Gary Goospaster sebagaimana diuraikan Rachmadi Usman, disebutkan bahwa 'mediasi adalah proses negosiasi pemecahan masalah, dan pihak luar yang tidak memihak (impartial) dan netral bekerja dengan pihak yang bersengketa untuk membantu mendapatkan kesepakatan perjanjian dengan memuaskan. Berbeda dengan hakim atau arbiter, mediator tidak mempunyai wewenang untuk memutuskan sengketa antara pihak'. ${ }^{58}$

55 Temitayo Bello, "Mediation-Negotiation: A Template Theraphy for Global Conflict," SSRN Electronic Journal, last modified 2019, https://papers.ssrn.com/sol3/papers.cfm?abstract_id=3 474429.

56 Lew Julian and Et Al, Comparative International Commercial Arbitration (Netherlands: Kluwer Law International, 2003); Bello, "Mediation-Negotiation: A Template Theraphy for Global Conflict."

57 Bello, "Mediation-Negotiation: A Template Theraphy for Global Conflict."

58 Rachmadi Usman, Pilihan Penyelesaian Sengketa Di Luar Pengadilan (Bandung: PT Citra Aditya Bakti, 2003); Syahrial Abbas, Mediasi Dalam Perspektif Hukum Syariah, Hukum Adat Dan Hukum Nasional (Jakarta: Kencana - Prenada Media Group, 2009); Djumhana, Djubaedillah, and Muhammad,Djumhana, Hak Milik Intelektual: Sejarah, Teori, Dan Praktiknya Di Indonesia. h. 128 


\author{
Unsur-unsur mediasi menurut Joni \\ Emirzon, yaitu: ${ }^{59}$ \\ 1. penyelesaian sengketa sukarela; \\ 2. intervensi atau bantuan; \\ 3. pihak ketiga tidak berpihak; \\ 4. pengambilan keputusan oleh para pihak \\ secara konsensus; \\ 5. partisipasi aktif.
}

Sedangkan istilah konsoliasi menurut Temitayo Bello, the term 'conciliation' is sometimes used to describe the same process of involving third parties, usually in the context of labour relations when neutral intervention is used to break a stalemate, domestic relations or international commercial matters. However, in recent times mediation and conciliation have being used interchangeably"60.

Bentuk penyelesaian sengketa selanjutnya dapat melalui arbitrase, yang oleh Alan Redfen dan J. Martin Hunter disebutkan bahwa arbitrase merupakan metode penyelesaian sengketa yang kerap kali digunakan dan terus bertambah seiring berkembangnya perdagangan dan investasi internasional. ${ }^{61}$

Selanjutnya penyelesaian sengketa dapat melalui Pengadilan niaga. Pengadilan niaga adalah suatu pengadilan khusus yang berada dalam lingkungan peradilan umum, yang dibentuk dan bertugas menerima, memeriksa, dan memutus, serta menyelesaikan permohonan pernyataan pailit dan penundaan kewajiban pembayaran utang serta perkara lain di bidang perniagaan. Saat ini, eksistensi pengadilan niaga mengacu pada ketentuan Pasal 1 angka 7 Undang-Undang Nomor 37 Tahun 2004 tentang Kepailitan dan Penundaan

59 Joni Emirzon, Alternatif Penyelesaian Sengketa Di Luar Pengadilan (Negosiasi, Mediasi, Konsiliasi, Dan Arbitrase) (Jakarta: Gramedia Pustaka Utama, 2001); Djumhana, Djubaedillah, and Muhammad,Djumhana, Hak Milik Intelektual: Sejarah, Teori, Dan Praktiknya Di Indonesia. h. 129

60 Bello, "Mediation-Negotiation: A Template Theraphy for Global Conflict."

61 Alan Redfern and J. Martin Hunter, Redfern and Hunter on International Arbitration, 6th ed. (Oxford: Oxford University Press, 2015); Carissa T.A Temenggung and Yetty Komalasari Dewi, "Pendanaan Pihak Ketiga (Third Party Funding) Dalam Penyelesaian Sengketa Melalui Arbitrase Dan Kemungkinan Penerapannya Di Indonesia," Jurnal Hukum \& Pembangunan 50, no. 2 (2020): 379-399.
Kewajiban Pembayaran Utang. ${ }^{62}$ Penyelesaian sengketa kekayaan intelektual melalui Pengadilan Niaga pada pokoknya memberi peluang pada para pihak untuk menyelesaikan sengketanya dalam waktu yang relatif singkat bila dibandingkan dengan proses peradilan melalui Pengadilan Negeri. ${ }^{63}$

Penyelesaian sengketa secara efektif yang ditawarkan dalam UU HC 28/2014 adalah melalui proses mediasi, arbitrase atau pengadilan, serta penerapan delik aduan untuk tuntutan pidana ${ }^{64}$, sebagaimana yang disebutkan dalam Pasal 120 UU HC, maka dasar pemeriksaan dari semua jenis tindak pidana di dalam UU HC adalah dalam bentuk pengaduan, bukan laporan. ${ }^{65}$

Sedangkan menurut Wasita, ${ }^{66}$ cara paling efektif dalam menyelesaikan sengketa perjanjian lisensi film antara produser dan distributor adalah dengan negosiasi dan arbitrase. Penyelesaian nasional sangat tidak dianjurkan karena selain memakan waktu yang lama dan sulit diimplementasikan.

\section{PENUTUP}

\section{Kesimpulan}

Berdasarkan pembahasan yang sudah diuraikan di atas, maka kesimpulan pada penulisan ini adalah, bentuk-bentuk pelanggaran yang dilakukan lembaga pemerintah dalam hal ini Kemendikbud pada kasus penayangan film dokumenter 'Sejauh Kumelangkah' perlu dilakukan beberapa telaah dan konfirmasi kepada kedua belah pihak terlebih dahulu. Namun berdasarkan siaran pers yang sudah disampaikan pada beberapa media, kesimpulan sementara Kemendikbud dalam hal ini telah melakukan pelanggaran Pada Pasal 5 Ayat (1) huruf e, dan Pasal 9 Ayat

62 Djumhana, Djubaedillah, and Muhammad,Djumhana, Hak Milik Intelektual: Sejarah, Teori, Dan Praktiknya Di Indonesia. h. 125-126

63 Eben Paulus Muaja, "Kewenangan Pengadilan Niaga Dalam Penyelesaian Sengketa HAKI Di Bidang Hak Cipta Menurut Undang-Undang Nomor 28 Tahun 2014," Lex Crimen VII, no. 6 (2018): 89-96.

64 Lihat penjelasan Undang-Undang Republik Indonesia Nomor 28 Tahun 2014 tentang Hak Cipta Bagian I Umum, huruf c. h. 2

65 Duwi Handoko, "Legal Politics of Criminalization and Decriminalization in Copyright," Jurnal Ilmiah Kebijakan Hukum 13, no. 1 (2019): 99-122.

66 Wasita, "Perlindungan Hukum Pemegang Hak Cipta Atas Film Impor." 
(1) huruf c, dan d Undang-Undang Nomor 28 Tahun 2014 tentang Hak Cipta. Sebagai langkah Preventif agar dikemudian hari kita dapat lebih berhati-hati, maka kita semestinya (i) Memahami aturan-aturan hukum yang berlaku terkait hak cipta; (ii) Menjalankan kesepakatan dalam perjanjian sebagaimana yang disepakati antara para pihak, dengan memenuhi asas-asas dalam perjanjian; (iii) Menjalankan perjanjian yang tidak melawan hukum atau peraturan perundang-undangan. Sedangkan untuk penyelesaian sengketa yang dapat ditempuh, somasi kepada pihak yang bersangkutan, bila somasi tidak mendapat tanggapan, dapat membuat laporan pengaduan langsung ke Direktorat Jenderal Kekayaan Intelektual untuk mediasi dan penyelidikan oleh Penyidik Pegawai Negeri Sipil, atau dapat menyelesaikan sengketa dengan jalur arbitrase atau jalur penyelesaian sengketa lainnya, atau bisa juga mengajukan gugatan ganti rugi ke Pengadilan Niaga. Selain gugatan, orang yang merasa dirugikan juga dapat melaporkan delik pidana.

\section{Saran}

1. Kepada produser, sutradara, pemilik, dan/atau pemegang hak cipta agar lebih berhati-hati dalam menjalin kerja sama dengan pihak mana pun, terlebih dahulu pastikan memahami aturan dan semua syarat perjanjian lisensi terpenuhi.

2. Kepada lembaga pemerintah atau pihak mana pun yang hendak menjalin kerja sama terkait hak cipta, untuk lebih berhatihati, pahami dahulu ketentuan hukumnya, kemudian menjalankan sesuai dengan perjanjian yang berlaku. Terutama untuk lembaga pemerintah, seharusnya dapat menjadi contoh yang baik kepada masyarakat.

\section{UCAPAN TERIMA KASIH}

Assalamualaikum wr. wb., ucapan terima kasih saya haturkan kepada guru besar kami Prof. Agus Sardjono, S.H., M.H. (Universitas Indonesia), yang sudah menerima dan memberi masukan pada penulisan ini. Juga tak lupa saya haturkan terima kasih kepada guru besar kami, Prof. Dr. Agus Yudho Hernoko, S.H., M.H., dan Prof. Dr. Peter Mahmud Marzuki, MS., LL.M, (Universitas Airlangga) yang hingga saat ini ilmu beliau masih saya gunakan. Semoga penulisan ini bermanfaat. Terima kasih.

\section{DAFTAR PUSTAKA}

Abbas, Syahrial. Mediasi Dalam Perspektif Hukum Syariah, Hukum Adat Dan Hukum Nasional. Jakarta: Kencana - Prenada Media Group, 2009.

Aditya, Rifan, and Farah Nabila. "TVRI Tayangkan Film Sejauh Kumelangkah Tanpa Izin, Kemendikbud Minta Maaf." Suara.Com 10 Oktober 2020. Last modified 2020. Accessed December 13, 2020.

https://www.suara.com/news/2020/10/10/1 32044/tvri-tayangkan-film-sejauhkumelangkah-tanpa-izin-kemendikbudminta-maaf?page=all.

Badrulzaman, Mariam Darus, and Et Al. Kompilasi Hukum Perikatan. Bandung: Citra Aditya Bakti, 2001.

Bello, Temitayo. "Mediation-Negotiation: A Template Theraphy for Global Conflict." SSRN Electronic Journal. Last modified 2019.

https://papers.ssrn.com/sol3/papers.cfm?a bstract id $=3474429$.

Burton, Steven J., and Eric G. Andersen. Contractual Goodfaith (Formation, Performance, Breach, Enforcement). Kanada: Little, Brown and Company, 1995.

Dawson, John P. Contracts (Case and Comment). New York: The Foundation Press, 1982.

Djumhana, Muhamad, R. Djubaedillah, and R Djubaedilah Muhammad,Djumhana. Hak Milik Intelektual: Sejarah, Teori, Dan Praktiknya Di Indonesia. Revisi. Bandung: PT. Citra Aditya Bakti, 2014.

Dunne, J.M. van. Verbintenissenrecht (Deel 1, Contractenrecht, 1e Gedeelte). KluwerDeventer, 1993.

Emirzon, Joni. Alternatif Penyelesaian Sengketa Di Luar Pengadilan (Negosiasi, Mediasi, Konsiliasi, Dan Arbitrase). Jakarta: Gramedia Pustaka Utama, 2001.

Gumanti, Retna. "Perjanjian Lisensi Di Indonesia." Al-Mizan Vol. 12 (2016): 245260.

http://journal.iaingorontalo.ac.id/index.php/ am.

Haanapel, P.P.C, and Ejaan Mackaay. Nieuw Nederlands Burgelijk Wetboek (Het Vermogensrecht). Deventer: Kluwer Law and Taxation Publisher, 1990.

Hadjon, Philipus M. Perlindungan Hukum Bagi Rakyat Di Indonesia. Surabaya: Bima IImu Surabaya, 1987. 
Handoko, Duwi. "Legal Politics of Criminalization and Decriminalization in Copyright." Jurnal IImiah Kebijakan Hukum 13, no. 1 (2019): 99-122.

Harjono, Zakki Adlhiyati, Moch Najib Imanullah, and Sri Wahyuningsih Yuliati. Hukum Acara Penyelesaian Sengketa Kekayaan Intelektual. Malang: Setara Press, 2019.

Hernoko, Agus Yudha. Hukum Perjanjian: Asas Proporsionalitas Kontrak Komersial. Pertama. Jakarta: Kencana - Prenada Media Group, 2010.

Indonesia, CNN. "Kemendikbud Minta Maaf Ke Sutradara Film Sejauh Kumelangkah." 10 Oktober 2020. Last modified 2020. Accessed December 13, 2020. https://www.cnnindonesia.com/nasional/20 201010105047-20-556788/kemendikbudminta-maaf-ke-sutradara-film-sejauhkumelangkah.

-. "Sutradara 'Sejauh Ku Melangkah' Tolak Maaf Kemendikbud." 13 Oktober 2020. Last modified 2020. Accessed December 13, 2020. https://www.cnnindonesia.com/nasional/20 201013141155-12-557867/sutradarasejauh-ku-melangkah-tolak-maafkemendikbud.

Infoscreening.co. "Minikino \& Sutradara Ucu Agustin Luncurkan Film 'Sejauh Kumelangkah' Versi Inklusif." Infoscreening. Co 17 November 2020. Last modified 2020. Accessed December 13, 2020. https://infoscreening.co/peluncuranfilm-sejauh-kumelangkah-versi-inklusif/.

Isnaeni, M. Hipotek Pesawat Udara Di Indonesia. Surabaya: Dharma Muda, 1996.

Iswi Hariyani, and dkk. Buku Pintar HAKI Dan Warisan Budaya. Yogyakarta: UGM Press, 2018.

Iswi Haryani, Cita Yustisia Serfiyani, R. Serfianto D. Purnomo, Iswi Hariyani, Cita Yustisia Serfiyani, and R. Serfianto Purnomo. Hak Kekayaan Intelektual Sebagai Jaminan Kredit. Edited by Dwi Prabantini. I. Yogyakarta: ANDI, 2018.

Julian, Lew, and Et Al. Comparative International Commercial Arbitration. Netherlands: Kluwer Law International, 2003.

Kansil, C.S.T. Hak Milik Intelektual. Jakarta: Bumi Aksara, 1990.

Kemdikbud, Pengelola Web. "Perluas Akses Belajar Di Masa Covid-19, Mendikbud Luncurkan Program Belajar Dari Rumah." Siaran Pers Nomor:083/Sipres/A6/IV/2020.
Last modified 2020. Accessed December 14 , 2020. https://www.kemdikbud.go.id/main/blog/20 20/04/perluas-akses-belajar-di-masacovid19-mendikbud-luncurkan-programbelajar-dari-rumah\#: :text=\%22Program Belajar dari Rumah mulai,selama 3 bulan ke depan.

Kusumawardani, Qur'ani Dewi. "Legal Protection for Internet Users Against Web Contents with Clickbait on Online Media." Jurnal Penelitian Hukum De Jure 19, no. 1 (2018): 11-30.

Lestari, Hesty D. "Kepemilikan Hak Cipta Dalam Perjanjian Lisensi (Kajian Putusan Mahkamah Agung Nomor 104 PK/PDT.SUS/2011." Jurnal Yudisial 6, no. No. 2 (2013). https://jurnal.komisiyudisial.go.id/index.php /jy/article/view/112.

Marzuki, Peter Mahmud. Penelitian Hukum. Revisi. Jakarta: Kencana - Prenada Media Group, 2005.

Muaja, Eben Paulus. "Kewenangan Pengadilan Niaga Dalam Penyelesaian Sengketa HAKI Di Bidang Hak Cipta Menurut Undang-Undang Nomor 28 Tahun 2014." Lex Crimen VII, no. 6 (2018): 89-96.

Newman, Christopher M. "A License Is Not a 'Contract Not to Sue': Disentangling Property and Contract in the Law of Copyright Licenses." Journal Lowa Law Review 98 (2013).

Niewenhuis, J.H. Pokok-Pokok Hukum Perikatan. Edited by Terjemahan Djasadin Saragih. Surabaya, 1985.

Paramarta, I Gusti Bagus Arya Anggara. "Akibat Hukum Perjanjian Lisensi Terhadap Pihak Ketiga." Acta Comitas I (2007): 75-83.

Patrik, Purwahid. Dasar-Dasar Hukum Perikatan. Bandung: Mandar Maju, 1994.

Presiden RI. Undang-Undang Republik Indonesia Nomor 28 Tahun 2014 Tentang Hak Cipta. Indonesia, 2014.

Redfern, Alan, and J. Martin Hunter. Redfern and Hunter on International Arbitration. 6th ed. Oxford: Oxford University Press, 2015.

Santoso, Bangun, and Stephanus Randitio. "Disomasi Langgar Hak Cipta Fllm Sejauh Kumelangkah, Ini Reaksi Kemendikbud." Suara.Com 05 Oktober 2020. Last modified 2020. https://www.suara.com/news/2020/10/05/1 02712/disomasi-langgar-hak-cipta-filmsejauh-kumelangkah-ini-reaksikemendikbud. 
Schuit, Steven R. et al. Dutch Business Law. Antwerp-Boston-London-Frankfurt: Kluwer Kaw \& Taxation Publisher, 1983.

Setiawan. Pokok-Pokok Hukum Perikatan. Cet. IV. Jakarta: Binacipta, 1987.

Setiawan, Riyan. "Sutradara Film Sejauh Melangkah Tak Puas Jawaban Kemendikbud \& TVRI." Tirto. ID 13 Oktober 2020. Last modified 2020. Accessed December 13, 2020. https://tirto.id/sutradara-film-sejauhmelangkah-tak-puas-jawabankemendikbud-tvri-f5SY.

Simanjuntak, P.N.H. Pokok-Pokok Hukum Perdata Indonesia. Jakarta: Ikrar Mandiri Abadi, 2005.

Sjahdeini, Sutan Remi. Kebebasan Berkontrak Dan Perlindungan Yang Seimbang Bagi Para Pihak Dalam Perjanjian Kredit Bank Di Indonesia. Jakarta: Institut Bankir Indonesia, 1993.

Soemantoro. Masalah Pengaturan Alih Teknologi. Bandung: Alumni, 1993.

Subekti. Aneka Perjanjian. Cet. Keena. Bandung: Alumni, 1995.

Subekti, R., and R. Tjitrosudibio. Burgerlijk Wetboek (BW), n.d.

Sudaryat, Sudjana, and Rika Ratna Permata. Hak Kekayaan Intelektual: Memahami Prinsip Dasar, Cakupan, Dan UndangUndang Yang Berlaku. Bandung: Oase Media, 2010.

Suryoningrat, R.M. Asas-Asas Hukum Perikatan. Bandung: Tarsito, 1985.

Temenggung, Carissa T.A, and Yetty Komalasari Dewi. "Pendanaan Pihak Ketiga (Third Party Funding) Dalam Penyelesaian Sengketa Melalui Arbitrase Dan Kemungkinan Penerapannya Di Indonesia." Jurnal Hukum \& Pembangunan 50, no. 2 (2020): 379-399.

Usman, Rachmadi. Pilihan Penyelesaian Sengketa Di Luar Pengadilan. Bandung: PT Citra Aditya Bakti, 2003.

Wasita, Agus. "Perlindungan Hukum Pemegang Hak Cipta Atas Film Impor." Jurnal BECOSS (Business Economic, Communication, and Social Sciences 2, no. No. 2 (2020): 1-12. https://journal.binus.ac.id/index.php/BECO SS/article/view/6132/3827.

Wiradirja, Imas Rosidawati, and Fontian Munzil. Pengetahuan Tradisional \& Kekayaan Intelektual: Perlindungan Pengetahuan Tradisional Berdasarkan Asas Keadilan Melalui Sui Generis Intellectual Property
System. Bandung: PT Refika Aditama, 2018.

Zainal, Zaidah. "Case Study as A Research Method." Jurnal Kemanusiaan Vol. 5 No. (2007).

"Disomasi Sutradara Film 'Sejauh Kumelangkah', Ini Respon Kemendikbud." Tribunnews.Com 5 Oktober 2020. Last modified 2020. Accessed December 13, 2020.

https://www.tribunnews.com/nasional/2020 /10/05/disomasi-sutradara-film-sejauhkumelangkah-ini-responkemendikbud?page $=2$.

"Disomasi Sutradara IIm Sejauh Kumelangkah, Kemendikbud Akui Lakukan Kesalahan." DW Made For Minds, 5 Oktober 2020.

Kamus Besar Bahasa Indonesia (KBBI) V 0.40.0 Beta (40). Edisi Keli. Jakarta: Badan Pengembangan Bahasa dan Perbukuan, Kementerian Pendidikan dan Kebudayaan Republik Indonesia, n.d. kbbi.kemdikbud.go.id.

"Manual Book Aplikasi E-HakCipta." In Manual E-Book. Jakarta: Direktorat Teknologi Informasi, Direktorat Jenderal Kekayaan Intelektual, n.d.

"Peluncuran Program: 'Belajar Dari Rumah."' Kemdikbud RI Youtube Channel. Last modified 2020. Accessed December 13, 2020.

https://www.youtube.com/watch?v=21axUk EQhOQ. 